\title{
Risk Analysis of Microplastic in Fish (Nemiptus Japonicas \& Rastrelliger Sp.) in Communities in the Coast Area of Tamasaju, Galesong Takalar
}

\author{
Anwar Daud ${ }^{1}$, Agus Bintara Birawida ${ }^{1}$, Hasnawati Amqam ${ }^{1}$, \\ Akbar Tahir ${ }^{2}$, Nano Hajrah $\mathrm{El}^{3}$, Lisawati Nurtang ${ }^{3}$ \\ ${ }^{1}$ Department of Environmental Health, Faculty of Public Health, Hasanuddin University, ${ }^{2}$ Laboratory of \\ Ecotoxicology, Faculty of Marine Science and Fishery, Hasanuddin University, ${ }^{3}$ Student of Environmental Health \\ Departement, Faculty of Public Health, Hasanuddin University
}

\begin{abstract}
Plastic waste has become one of the most serious threats to the marine environment. Among the plastic waste of special concern is microplastic because of its small size. This study aimed to analyze the level of risk of microplastic exposure through fish consumption in communities in the coastal area of Tamasaju Village, North Galesong District, Takalar Regency. Microplastic abundance found as many as 18 particles, microplastic types found are the shape of a line or fiber with different color and size variations. Blue fiber dominates at $77.77 \%$. The average microplastic concentration (C) in fish is $0.2 \mathrm{mg} / \mathrm{kg}$. The respondents interviewed were 30 people and mostly fishermen. Average intake rate $(R) \pm 155$ grams/day, Average frequency of exposure (FE) of fish consumption \pm 190 days/year, Average duration of exposure (Dt) of fish consumption \pm 39 years and. Average respondent's weight $(\mathrm{Wb}) \pm 58 \mathrm{~kg}$. The average Non-Carcinogenic Intake Rate in fish consumption is $0.004754 \mathrm{mg} / \mathrm{kg} /$ day and the average Carcinogenic Intake Rate in fish consumption is $0.009328 \mathrm{mg} / \mathrm{kg} /$ day. The results of calculations with one-way ANOVA obtained P-Value $=0.009867<$ value $\alpha=0.05$, then there is a strong relationship with microplastic concentration, intake rate, frequency of exposure, and duration of exposure to Intake Rate or Risk (RQ).
\end{abstract}

Keywords: Risk Analysis, Microplastic, Coastal Areas, Fish.

\section{Introduction}

Plastic has become a part of everyday life, from clothing to coatings and vehicles to cleaning products. So that the losses caused by the abundance of plastic waste are very visible in the environment. A particular concern among plastic waste is microplastics due to their small size ${ }^{[1,2]}$. Microplastics are defined as small pieces of plastic smaller than five millimeters in size ${ }^{[3-5]}$

Globally, the discharge of primary microplastics into the sea is estimated at 1.5 million/year ${ }^{[3]}$. Most of

\footnotetext{
Corresponding Author:

Agus Bintara Birawida

Senior Lecturer, Department of Environmental Health, Faculty of Public Health, Hasanuddin University e-mail: agusbirawida@gmail.com
}

the microplastics come from a land that enters the marine environment, including those flowing through rivers ${ }^{[6,7]}$. Microplastics have been found in drinking water, bottled water ranges from 0 to more than 104 particles/ltr with an average value of 103 particles/ $/ \operatorname{tr}^{[8]}$.

The consumption of microplastics by fish is closely related to plastic pollution in the marine environment $[2,9,10]$. Microplastics digested by fish are dominated by microplastics that are $<1 \mathrm{~mm}$ in size, film-like shaped,and transparent in color ${ }^{[11,12]}$. Also, microplastic particles are found in sediments and filterfeeding animals ${ }^{[13]}$.

In Indonesia, plastic waste pollution has reached serious limits, according to Jambeck et al. (2015) Indonesia occupied $2^{\text {nd }}$ rank as a country that produces vast plastic waste ${ }^{[14]}$. Indonesia contributes $0.48-1.29$ million metric tons of plastic waste to the sea every year. 
Thus, in Indonesia, total plastic waste is predicted to reach 9.52 million tonnes in $2019^{[15]}$. The identification of microplastics in the Makassar region has not found any alarming cases, including their effects on humans ${ }^{[16-19]}$ However, research, as conducted by Rochman (2015) at TPI Paotere Makassar, showed quite high results, namely the number of particles in each fish ranged from $0-21$ particles/individual ${ }^{[20]}$.

One of the famous auction place of fish in Makassar is Beba North Galesong in Takalar district. Various types of seafood are traded at this auction ${ }^{[21,22]}$, even visitors or buyers who come can directly enjoy the catch of fishermen which are provided in food stalls along the entrance to Beba auction place of fish, Tamasaju village, including a village that is very close to Beba auction place of fish. In this village, people have the main profession as fishermen, and most of the people here use seafood as their daily side dish.

The presence of microplastics in marine species that are often consumed by the people raises concerns about the level of risk of microplastics to human health. Therefore, in this study, we will examine the evidence of seafood contamination (fishes) by microplastics, and the level of risk from the presence of microplastics in the marine environment to human health.

\section{Methodology}

Type of Research: The type of research is descriptive analysis with the Environmental Health Risk Analysis approach, by using questionnaires, interviews, laboratory examinations, and calculations using its formula. This research will be conducted in May-June 2020. Fish samples were taken for 1 day at $06.00-07.00$ a.mon June 25, 2020, at the Bebaauction place of fish.
Fish samples were taken by random sampling, namely as many as 20 fish, 10 each of red curisi, and 10 mackerel. Furthermore, fish samples are stored in a coolbox and taken to the laboratory for analysis.

Laboratory analysis: Microplastic analysis consists of several stages ${ }^{[20]}$. These stages are sample preparation, dissolve organic matter with $\mathrm{KOH} \%$ solution, microplastic observation with a microscope, microplastic measurement using ImageJ software. The fish sample is dissected and separated from the intestine. The fish intestines are broken and then placed into the sample to extract plastic debris from the fish intestines. Each sample pot containing 10 grams of fish intestine was filled with $20 \%(20-50 \mathrm{ml}) \mathrm{KOH}$ (Potassium Hydroxide) solution up to 3 times the volume of tissue in ultrapure water and incubated for 7 days at room temperature to digest organic matter. For each sample, the digested material was carefully sorted and examined under the euromax nexius zoom trinocular microscope.

Statistical Analysis The statistical analysis method used in this research is a descriptive statistical test and one-way ANOVA.

\section{Results Dan Discussion}

Microplastic Identification in Fish: The fish found based on the respondent's consumption map were red kurisi fish (Nemiptus japonicas) and mackerel fish (rastrelliger sp.). Red kurisifish is demersal fish most often consumed by almost all coastal fishing families in Tamasaju village. Meanwhile, mackerel fish is pelagic fish which is also the favorite fish of the coastal residents of Tamasaju village, besides the price is very cheap it is also because the texture of this fish meat is very tasty after being processed.

Table 1. Types of microplastic-identified fishes

\begin{tabular}{|c|l|c|c|}
\hline No & Names of species & Identification of fishes in reference & Type of fishes found \\
\hline 1 & $\begin{array}{l}\text { Demersal fish: red kurisi fish } \\
\text { (Nemiptus japonicas) }\end{array}$ & $\begin{array}{l}\text { Source: }{ }^{[23]} \\
\text { Pelagic fish: mackerel fish } \\
\text { (rastrelliger } s p .) .\end{array}$ & \\
\hline
\end{tabular}

The identification result of microplastics in red kurisi fish is shown in the table below. 
Table 2. Analysis result of microplastic in red kurisi fish

\begin{tabular}{|c|c|c|c|c|c|c|c|c|}
\hline \multirow{3}{*}{ No } & \multirow{3}{*}{\multicolumn{2}{|c|}{ Code of sample }} & \multicolumn{5}{|c|}{ Parameter } & \multirow{3}{*}{ Rearing } \\
\hline & & & \multicolumn{4}{|c|}{ Microplastic } & \multirow{2}{*}{$\begin{array}{c}\text { Abund } \\
(\mathrm{M} / \mathrm{I})\end{array}$} & \\
\hline & & & Shape & Color & Size (mm) & Weight (gram) & & \\
\hline 1 & \multirow{17}{*}{$\begin{array}{l}\text { D (Red kurisi fish) } \\
\text { Nemiptus japonicas } \\
\text { (Bleeker, 1851) }\end{array}$} & Blanko D & - & - & - & - & 0 & \\
\hline 2 & & D1 & Line & Blue & 1,394 & 0,0001 & 1 & 4.5 \\
\hline \multirow{2}{*}{3} & & \multirow{2}{*}{ D2 } & Line & Blue & 0,678 & 0,0004 & \multirow{2}{*}{2} & 4.5 \\
\hline & & & Line & Blue & 1,317 & 0,0002 & & 4.5 \\
\hline 4 & & D3 & - & - & - & & 0 & \\
\hline 5 & & D4 & - & - & - & & 0 & \\
\hline 6 & & D5 & - & - & - & & 0 & \\
\hline \multirow{4}{*}{7} & & \multirow{4}{*}{ D6 } & Line & Mix & 1,401 & 0,0001 & \multirow{4}{*}{4} & 4.5 \\
\hline & & & Line & Blue & 1,152 & 0,0001 & & 4.5 \\
\hline & & & Line & Blue & 1,365 & 0,0000 & & 4.5 \\
\hline & & & Line & Blue & 2,505 & 0,0005 & & 4.5 \\
\hline 8 & & D7 & - & - & - & & 0 & \\
\hline 9 & & D8 & - & - & - & & 0 & \\
\hline \multirow{3}{*}{10} & & \multirow{3}{*}{ D9 } & Line & Purple & 1,721 & 0,0001 & \multirow{3}{*}{3} & 4.5 \\
\hline & & & Line & Blue & 2,168 & 0,0001 & & 4.5 \\
\hline & & & Line & Green & 1,327 & 0,0003 & & 4.5 \\
\hline 11 & & D10 & Line & Blue & 0,68 & 0,0002 & 1 & 4.5 \\
\hline
\end{tabular}

Microplastic content was only found in samples D1, D2, D6, D9, and D10 as shown in Table 2. Total microplastics found in red kurisi fish were 11 particles. Generally, the types of microplastics found are lineshaped microplastics, consisting of blue, mix, purple, and green colors ${ }^{[24]}$. The largest microplastic size of $2.168 \mathrm{~mm}$ is found in sample D9 in the form of blue lines, and the smallest microplastic size of $0.68 \mathrm{~mm}$ is found in sample D10 in the form of a blue line. The largest abundance of microplastics was found in sample D6, namely 4 microplastics/individual, and the smallest abundance of microplastics was found in samples D1 and D10, namely 1 microplastic/individual. While, samples D3, D4, D5, D7, D8 were not found to contain microplastics.

The identification result of microplastic in mackerel fish is shown in the table below. 
Table 3. Analysis result of microplastic in mackerel fish

\begin{tabular}{|c|c|c|c|c|c|c|c|c|}
\hline \multirow{3}{*}{ No } & \multirow{3}{*}{\multicolumn{2}{|c|}{ Code of sample }} & \multicolumn{5}{|c|}{ Parameter } & \multirow{4}{*}{ Rearing } \\
\hline & & & \multicolumn{4}{|c|}{ Microplastic } & \multirow{2}{*}{$\begin{array}{c}\text { Abund } \\
(\mathrm{M} / \mathrm{I})\end{array}$} & \\
\hline & & & Shape & Color & Size (mm) & $\begin{array}{l}\text { Weight } \\
\text { (gram) }\end{array}$ & & \\
\hline 1 & $\mathrm{P}$ & Blanko P & - & - & - & & 0 & \\
\hline 2 & \multirow{13}{*}{ Rastrelligerbracysoma } & $\mathrm{P} 1$ & Line & Blue & 3,122 & 0,0004 & 1 & 4.5 \\
\hline 3 & & \multirow{2}{*}{$\mathrm{P} 2$} & Line & Blue & 0,713 & 0,0001 & \multirow{2}{*}{2} & 4.5 \\
\hline$J$ & & & Line & Blue & 0,921 & 0,0001 & & 4.5 \\
\hline \multirow{2}{*}{4} & & \multirow{2}{*}{ P3 } & Line & Blue & 3,584 & 0,0003 & \multirow{2}{*}{2} & 4.5 \\
\hline & & & Line & Mix & 2,08 & 0,0004 & & 4.5 \\
\hline 5 & & P4 & - & - & - & & 0 & \\
\hline 6 & & P5 & - & - & - & & 0 & \\
\hline \multirow{2}{*}{7} & & \multirow{2}{*}{ P6 } & Line & Blue & 2,03 & 0,0001 & \multirow{2}{*}{2} & 4.5 \\
\hline & & & Line & Blue & 0,926 & 0,0001 & & 4.5 \\
\hline 8 & & P7 & - & - & - & & 0 & \\
\hline 9 & & P8 & - & - & - & & 0 & \\
\hline 10 & & P9 & - & - & - & & 0 & \\
\hline 11 & & $\mathrm{P} 10$ & - & - & - & & 0 & \\
\hline
\end{tabular}

Microplastic content was only found in samples $\mathrm{P} 1, \mathrm{P} 2, \mathrm{P} 3$, and P6 as shown in Table 3. The total microplastics found in mackerel fish were 7 particles. Generally, the types of microplastics found are lineshape microplastics, which consist of blue and mix colors. The largest microplastic size of $3.854 \mathrm{~mm}$ was found in the P3 sample in the form of a blue line, and the smallest microplastic size of $0.713 \mathrm{~mm}$ was found in the P2 sample in the form of a blue line. The abundance of microplastics in samples P2, P3, and P6 is 2 microplastics/individual and the abundance of microplastics is 1 microplastic/individual in sample P1. Meanwhile, samples of P4, P5, P7, P8, P9, and P10 were not found to contain microplastic.

Microplastic Abundance of Fishes: Generally, the type of microplastic found was line-shaped microplastic, consist of blue, mix, purple, and green colors.

Table 4 shows the shape of microplastic found in the fish's body is generally line and fiber-shaped. Meanwhile, the most dominant of amount color is blue as many $77.77 \%$.
Table 4. The proportion of microplastic found in fishes by shape and color

\begin{tabular}{|c|l|l|c|c|}
\hline No & Shape & Color & Total & \% \\
\hline 1 & Line & Blue & 14 & $77.77 \%$ \\
\hline & & Mix & 2 & $11.11 \%$ \\
\hline & & Purple & 1 & $5.50 \%$ \\
\hline & & Green & 1 & $5.50 \%$ \\
\hline & Total Particle & & $\mathbf{1 8}$ & $\mathbf{1 0 0 \%}$ \\
\hline
\end{tabular}

Risk Analysis of MPs Exposure to Human: The step of EHRA is a risk characteristic that conducted to determine the risk or one other hand to determine whether the risk agentsat a certain concentration of EHRA by the Directorate General of PP and PL, the Ministry of Health ${ }^{[25]}$ and relevant study about health risk assessment ${ }^{[26]}$ were analyzed for risky EHRA arise health disturbance by the communities or not. Risk analysis of microplastic exposure for humans refers to the guideline book.

\section{The Calculation of Ingestion Path Intake Rate}

The following is the calculation result of Intake rate through ingestion exposure (digested): 
Table 5. The calculation result of non-carcinogenic and carcinogenic intake rate

\begin{tabular}{|c|c|c|c|c|c|c|c|c|}
\hline No. & Code of Resp. & $\mathrm{C} \mathrm{mg/kg}$ & R kg/day & FE day/yr & Dt years & Wb kg & I Non-Carc & I Carc \\
\hline 1 & SA1 & 2.5 & 0.08 & 208 & 60 & 50 & 0.005 & 0.002 \\
\hline 2 & SA2 & 2.5 & 0.16 & 156 & 30 & 50 & 0.003 & 0.001 \\
\hline 3 & SA3 & 5 & 0.08 & 208 & 22 & 60 & 0.003 & 0.001 \\
\hline 4 & SA4 & 2.5 & 0.16 & 156 & 45 & 62 & 0.004 & 0.002 \\
\hline 5 & SA5 & 2.5 & 0.16 & 208 & 20 & 60 & 0.003 & 0.001 \\
\hline 6 & SA6 & 1 & 0.2 & 156 & 44 & 85 & 0.001 & 0.001 \\
\hline 7 & SA7 & 4 & 0.1 & 208 & 21 & 45 & 0.004 & 0.002 \\
\hline 8 & SA8 & 5 & 0.08 & 208 & 45 & 52 & 0.007 & 0.003 \\
\hline 9 & BB1 & 2.5 & 0.24 & 208 & 37 & 60 & 0.007 & 0.003 \\
\hline 10 & BB2 & 2.5 & 0.16 & 156 & 50 & 70 & 0.004 & 0.002 \\
\hline 11 & BB3 & 2.5 & 0.16 & 260 & 20 & 65 & 0.003 & 0.001 \\
\hline 12 & BB4 & 2.5 & 0.16 & 208 & 55 & 63 & 0.007 & 0.003 \\
\hline 13 & BB5 & 1.25 & 0.32 & 208 & 40 & 60 & 0.005 & 0.002 \\
\hline 14 & BB6 & 2.5 & 0.16 & 208 & 55 & 45 & 0.009 & 0.004 \\
\hline 15 & BB7 & 2.5 & 0.16 & 208 & 60 & 50 & 0.009 & 0.004 \\
\hline 16 & CA1 & 3.33 & 0.12 & 260 & 36 & 60 & 0.006 & 0.002 \\
\hline 17 & CA2 & 5 & 0.08 & 260 & 45 & 65 & 0.007 & 0.003 \\
\hline 18 & CA3 & 2 & 0.1 & 208 & 42 & 45 & 0.004 & 0.002 \\
\hline 19 & CA4 & 2.5 & 0.24 & 208 & 48 & 72 & 0.008 & 0.003 \\
\hline 20 & CA5 & 2.5 & 0.16 & 260 & 40 & 50 & 0.008 & 0.003 \\
\hline 21 & CA6 & 5 & 0.08 & 260 & 55 & 56 & 0.009 & 0.004 \\
\hline 22 & CA7 & 2.5 & 0.16 & 156 & 36 & 62 & 0.003 & 0.001 \\
\hline 23 & CA8 & 1.25 & 0.32 & 156 & 46 & 62 & 0.004 & 0.002 \\
\hline 24 & $\mathrm{BC} 1$ & 2 & 0.2 & 156 & 10 & 50 & 0.001 & 0.000 \\
\hline 25 & $\mathrm{BC} 2$ & 10 & 0.04 & 156 & 57 & 38 & 0.009 & 0.004 \\
\hline
\end{tabular}

Table 5 shows that the mean body weight of respondents is $\pm 58 \mathrm{~kg}$, with the lowest body weight in the $\mathrm{BC} 2$ sample, namely $38 \mathrm{~kg}$, and the highest body weight in the SA6 sample, namely $85 \mathrm{~kg}$. The average intake rate is \pm 155 grams/day of processed dry weight, where the minimum intake rate value is 40 grams/day in the $\mathrm{BC} 2$ sample and the maximum intake rate value is 320 grams/day in the BB5 and the CA8 samples. Generally, fish consumption by respondents is $1-2 \mathrm{fish} /$ day and 6 fish/week. The average frequency of exposure to fish consumption of \pm 190 days/year with a minimum frequency of exposure of 104 days/year is found in the $\mathrm{BC} 4$ and the BC5 samples and the maximum value of frequency of exposure 260 days/year are found in
BB3, CA1, CA2, CA5, and CA6 samples. The average duration of exposure to fish consumption was \pm 39 years with a minimum exposure duration value of 10 years in BC 1 and BC 7 samples, and the maximum duration of exposure was 60 years in SA1 and BB7 samples.

Based on the above tables is obtained the calculation result of the intake rate for respondents both carcinogenic and non-carcinogenic. If the intake rate $<\mathrm{RfD}$ (Reference Dose) then it is safe, otherwise if the intake rate $>R f D$ (Reference Dose) then it is not safe. Meanwhile, RfD of microplastic is not yet determined by EPA, then the first RfD microplastic must be found by using the derivation of NOEL's formula. 
Table 6. Result of carcinogenic and non-carcinogenic intake rate

\begin{tabular}{|l|c|l|c|}
\hline \multicolumn{2}{|c|}{ I Non Carcinogenic } & \multicolumn{2}{c|}{ I Carcinogenic } \\
\hline Mean & 0.004754 & Mean & 0.002037599 \\
\hline Median & 0.004103 & Median & 0.001758547 \\
\hline Mode & 0.003546 & Mode & 0.001519635 \\
\hline Standard Deviation & 0.002549 & Standard Deviation & 0.001092592 \\
\hline Range & 0.008378 & Range & 0.003590718 \\
\hline Minimum & 0.00095 & Minimum & 0.000407045 \\
\hline Maximum & 0.009328 & Maximum & 0.003997763 \\
\hline Sum & 0.142632 & Sum & 0.061127963 \\
\hline Count & 30 & Count & 30 \\
\hline
\end{tabular}

The table above shows that deviation standard Inon carcinogenic $=0,002549<$ mean $=0,004754$. The minimum value of Intake Rate Non Carcinogenic= 0.00095 found in $\mathrm{BC} 7$ sample, and the maximum value of Intake Rate Carsinogenic $=0.009328$ found in CA6 sample. Meanwhile, deviation standard I-Carsinogenic $=0,001092592<$ mean $=0.002037599$. The minimum value of Intake Rate Carsinogenic $=0,000407045$ found in BC7 sample, and the maximum value of Intake Rate Carsinogenic $=0,003997763$ found in CA6 sample.

\begin{tabular}{|l|c|c|c|c|c|c|}
\hline \multicolumn{7}{|c|}{ Anova } \\
\hline Source of Variation & SS & df & MS & F & P-value & F crit \\
\hline Between Groups & 59.25 & 1 & 59.25 & 10.09 & 0.009 & 4.96 \\
\hline Within Groups & 58.70 & 10 & 5.87 & & & \\
\hline Total & $\mathbf{1 1 7 . 9 6}$ & $\mathbf{1 1}$ & & & & \\
\hline
\end{tabular}

Based on the calculation by using ANOVA is obtained $p$-value $=0,009867<\alpha=0,05$, then there isa relationship with microplastic concentration, intake rate, exposure frequency, and exposure duration on Intake Rate or magnitude of risk (RQ).

\section{Conclusion}

Microplastic as found in red kurisi fish (Nemiptus japonicas)is 11 particles, and mackerel fish (rastrelliger $s p$.) is 7 particles. Microplastic is found inthe line or fiber-shaped only. Blueline dominates other colors is $77.77 \%$. These lines or fiber-shaped microplastic is predicted comes from the degradation of fishnets, cover tarpaulin of fisherman boat, and seat layer along the edge of the coastal of Beba, Tamasaju village.

The calculation result of Intake Rate, both noncarcinogenic and carcinogenic showed a strong relationship with the concentration $(\mathrm{C})$ of microplastics in fish, intake rate $(\mathrm{R})$, frequency of exposure (FE), duration of exposure, and body weight $(\mathrm{Wb})$ of respondents.
Acknowledgments: Thanks to the Chief of Research and Community Service Institute of Hasanuddin University for providing the opportunity to research, the Laboratory of Aquatic Productivity and Fertility of the Hasanuddin University, Faculty of Marine and Fisheries Affairs for providing laboratory facilities, and to the communities of Tamasaju village that participates in this research so that this research can finish well and no obstacles.

Ethical Clearance: Our study was not directly applied on human, hence ethical clearance was not required.

Source of Funding: Chief of Research and Community Service Institute of Hasanuddin University.

Conflict of Interest: The authors have no affiliation with any organization with a direct or indirect financial interest in the subject matter discussed in the manuscript. 


\section{References}

1. Liu K, Wang X, Wei N, Song Z, Li D. Accurate quantification and transport estimation of suspended atmospheric microplastics in megacities: Implications for human health. Environ Int 2019. doi:10.1016/j.envint.2019.105127.

2. Lusher A, Hollman P, Mandoza-Hill J. J. Microplastics in fisheries and aquaculture. 2017. doi:dmd.105.006999 [pii]ไr10.1124/ dmd.105.006999.

3. Boucher J, Friot D. Primary microplastics in the oceans: A global evaluation of sources. 2017. doi:10.2305/iucn.ch.2017.01.en.

4. Kershaw PJ, Turra A, Galgani F. Guidelines for the monitoring and assessment of plastic litter in the ocean. 2019.

5. Daud A. No TitleDampak Kesehatan dan Lingkungan Mikriplastik dan Nanoplastik. 1st ed. Yogyakarta: CV. Gosyen Publishing; 2020.

6. Barboza LGA, Dick Vethaak A, Lavorante BRBO, Lundebye AK, Guilhermino L. Marine microplastic debris: An emerging issue for food security, food safety and human health. Mar Pollut Bull 2018. doi:10.1016/j.marpolbul.2018.05.047.

7. Baldwin Cc. Fao Species Identification Guide For Fishery Purposes. The Living Marine Resources Of The Western Central Pacific. Copeia 2003. Doi:10.1643/0045-8511(2001)003[0212:]2.0.Co;2.

8. World Health Organization. Microplastics in drinking-water. 2019.

9. Lu L, Luo T, Zhao Y, Cai C, Fu Z, Jin Y. Interaction between microplastics and microorganism as well as gut microbiota: A consideration on environmental animal and human health. Sci Total Environ 2019. doi:10.1016/j.scitotenv.2019.02.380.

10. Zhu L, Wang H, Chen B, Sun X, Qu K, Xia B. Microplastic ingestion in deep-sea fish from the South China Sea. Sci Total Environ 2019. doi:10.1016/j.scitotenv.2019.04.380.

11. Zhao J, Ran W, Teng J, Liu Y, Liu H, Yin X, et al. Microplastic pollution in sediments from the Bohai Sea and the Yellow Sea, China. Sci Total Environ 2018. doi:10.1016/j.scitotenv.2018.05.346.

12. Widianarko B, Hantoro I. Mikroplastik Dalam Seafood Dari Pantai Utara Jawa. Universitas Katolik Soegijapranata, 2018.

13. Jahan S, Strezov V, Weldekidan H, Kumar R,
Kan T, Sarkodie SA, et al. Interrelationship of microplastic pollution in sediments and oysters in a seaport environment of the eastern coast of Australia. Sci Total Environ 2019. doi:10.1016/j. scitotenv.2019.133924.

14. Jambeck JR, Geyer R, Wilcox C, Siegler TR, Perryman M, Andrady A, et al. Plastic waste inputs from land into the ocean. Science (80-) 2015. doi:10.1126/science.1260352.

15. Kementerian Lingkungan Hidup dan Kehutanan. Kementerian Lingkungan Hidup dan Kehutanan 2018.

16. Anagnostakos NP, Tortora GJ. Principles of anatomy \& physiology. 2nd ed. New York: Harper and Row; 1978.

17. Choudhury H, Hertzberg R, Rice G, Cogliano J, Mukerjee D, Teuschler L, et al. Supplementary Guidance for Conducting Health Risk Assessment of Chemical Mixtures. Risk Assess Fourm 2000.

18. Food and Agriculture Organization, World Health Organization. Risk management and food safety. Report of a. FAO Food Nutr Pap 1997.

19. Mallongi A, Birawida AB, Astuti RDP, Saleh M. Effect of lead and cadmium to blood pressure on communities along coastal areas of Makassar, Indonesia. Enferm Clin 2020. doi:10.1016/j. enfcli.2020.03.001.

20. Rochman CM, Tahir A, Williams SL, Baxa D V., Lam R, Miller JT, et al. Anthropogenic debris in seafood: Plastic debris and fibers from textiles in fish and bivalves sold for human consumption. Sci Rep 2015. doi:10.1038/srep14340.

21. Chandra M, Sitompul I, HS T, K SP, Sondakh GM. Kekayaan Laut Indonesia. Jakarta. Sekretariat Dewan Maritim Indonesia-Departemen Kelautan dan Perikanan; 2007.

22. Wariyono S, Maharomah Y. Mari Belajar Ilmu Alam Sekitar Kita. 1st ed. Jakarta: Pusat Perbukuan, Departemen Pendidikan Nasional; 2008.

23. Frose R, Pauly D. Fishbase. Decapterus macrosoma Bleeker, 1851. World Regist Mar Species n.d.http:// www.marinespecies.org/alphia.php? $\mathrm{p}=$ taxdetails $\&$ id=218426 (accessed August 3, 2020).

24. Yonvitner ., Setyobudiandi I, Fachrudin A, Affandi R, Riani E, Triramdani N. REVIEW INDIKATOR DARI INDEK PSA NOAA UNTUK IKAN PELAGIS KECIL (TEMBANG: Sardinella sp.; Famili Clupeidae) DAN IKAN DEMERSAL 
(KURISI: Nemipterus sp.; Famili Nemipteridae). Mar Fish J Mar Fish Technol Manag 2018. doi:10.29244/jmf.8.2.123-135.

25. Kementrian Kesehatan. Pedoman Analisis Risiko Kesehatan Lingkungan (ARKL) 2012:1-82.
26. Birawida $\mathrm{AB}$, Selomo $\mathrm{M}$, Mallongi A, Ismita UW, Suriah. Health risk assessment of coliform bacteria contamination in the dug well water with qmra to predict public health risk in small island, makassar. Indian J Public Heal Res Dev 2018. doi:10.5958/0976-5506.2018.01234.2. 